\title{
Między dźwiękiem, słowem i obrazem: o przestrzenności w muzyce
}

\section{Between sound, word and image: on spatiality in music}

\author{
Katarzyna Płaczek \\ INSTYTUT FILOLOGII ROMAŃSKIEJ, UNIWERSYTET IM. ADAMA MICKIEWICZA \\ AL. NiEPODLEGŁOŚCI 4, 61-874 POZNAŃ \\ $\mathrm{ka} \cdot \mathrm{placzek@gmail.com}$
}

\begin{abstract}
The aim of this paper is to analyse the role of space in the imagination of music listeners. It includes general observations on the place and the importance of the problem of space in musical studies and it explores the peculiarity of some aspects of the music reception. Furthermore, it focuses on the relationship between literature and $19^{\text {th }}$ century programme music in order to point different techniques used by composers to produce spatial associations in listeners' imagination.
\end{abstract}

\section{Problem przestrzeni w muzyce. Przegląd stanowisk i uwagi ogólne}

Muzyka i literatura to dziedziny działalności twórczej, którym od okresu starożytności przypisywano przede wszystkim wymiar czasowy, w przeciwieństwie do malarstwa, rzeźby i architektury, uznawanych za sztuki przestrzenne. W epoce średniowiecza muzyka stanowiła jedną z siedmiu artes liberales, będących podstawą ówczesnego wykształcenia uniwersyteckiego. Wraz z arytmetyką, geometrią i astronomią wchodziła w skład quadrivium, gdyż, tak jak i one, traktowana była jako nauka o liczbach - a dokładniej, o liczbach w czasie. Postrzeganie muzyki jako sztuki na wskroś czasowej utrwaliło się w tradycji na wiele stuleci - w 1838 roku Heinrich Heine wypowiadał się o niej w takich słowach:

[Muzyka] [s]toi między myślami a zjawiskiem jako poetycka pośredniczka między duchem a materią; jest z obu spokrewniona, a wszakże różna od obu: jest duchem, lecz duchem, który wymaga miary czasu; jest materią, lecz materią, która może obejść się bez przestrzeni (cyt. przez Szymańska-Stułka 2015: 25). 

Katarzyna Płaczek: Między dźwiękiem, stowem i obrazem: o
przestrzenności w muzyce

Z kolei niecałe sto lat później, w wydanej w 1929 roku powieści Aleksis, czyli traktat o daremnych zmaganiach, Marguerite Yourcenar pisała: „[d]źwięki [...] rozpościerają się w czasie, tak jak kształty mają swoje miejsce w przestrzeni i muzyka, dopóki nie zamilknie, zanurza się częściowo w przyszłość” (Yourcenar 1998: 90). Pokazywała tym samym, że i ona pojmuje muzykę jako sztukę, dla której podstawową kategorią jest czas.

Również wielu kompozytorów i teoretyków estetyki zwykło sytuować muzykę w opozycji do sztuk plastycznych. Igor Strawiński (1980: 22) określił ją mianem „sztuki chronomatycznej”, która, w odróżnieniu od malarstwa („sztuki spacjalnej”), jest materią, która „konstytuuje się w następstwie czasu". W tym miejscu warto również przywołać jedną z koncepcji Susanne Langer (1953: 84), zgodnie z którą każda dziedzina sztuki ma swoją „pierwotną iluzje” (,primary illusion”): jest nią podstawowe tworzywo, w którym istnieją jej elementy. Dla muzyki jest to czas, a dla sztuk wizualnych - przestrzeń ${ }^{1}$.

Nie powinno zatem dziwić, że uwagę badaczy podejmujących się analizy muzyki zajmowała przede wszystkim różnorako pojmowana czasowość utworu, podczas gdy uwikłania przestrzenne dzieła muzycznego rzadziej traktowano jako autonomiczny przedmiot badań. Zwykle rozpatrywano je w powiązaniu z innymi elementami, nie zaś jako odrębne zagadnienie.

W ostatnich dziesięcioleciach nastąpiła jednak wyraźna zmiana temat roli i znaczenia przestrzeni w muzyce uległ pewnemu „usamodzielnieniu” względem kategorii czasu, o czym świadczą monografie i artykuły poświęcone temu problemowi. Wielość i zróżnicowanie ujęć i metod wykorzystywanych w badaniach nad przestrzenią w muzyce nie pozwala wyszczególnić jednego, głównego nurtu studiów nad tym zagadnieniem. Badacze odwołują się bowiem do rozmaitych pojęć i teorii zaczerpniętych $\mathrm{z}$ filozofii (m.in. $\mathrm{z}$ filozofii przyrody, $\mathrm{z}$ filozofii egzystencjalno-hermeneutycznej Heideggera, fenomenologii Husserla i Merleau-Ponty'ego [por. Losiak 2005 i 2012, Polony 2007, Szymańska-Stułka 2015]), literaturoznawstwa (por. Okoński 2013), semiotyki (por. Agawu 1991, Tarasti 2008 i 2009, Tagg 2013: 155194), kognitywistyki, a także fizyki i, w szczególności, akustyki. Owo zróżnicowanie perspektyw nie powinno zresztą dziwić - muzykologia i teoria muzyki to dziedziny nauki o wysoce interdyscyplinarnym charakterze, na co zwraca uwagę Lissa (1974: 7). Zdaniem badaczki, „[m]uzykolog pragnący oddać się pracy naukowej może być historykiem

${ }^{1}$ Niecoinne spojr zenie na zagadnienie cza sow ości w sztuce proponuje Eggebrecht (1992:160). Zdaniem ba dacza, każda dziedzina sztuki m a charakter cza sowy, gdyż „[w]szystko istnieje w czasie mier zony m przez zegary. Potrzebują gotakże inne sztuki. Gdy czytam, potr zebuję czasu. Podobnie gdy oglądam obraz; może on nawet sam z siebie wy znaczać czas, jaki poświęcam poszczególny m jego częściom. Nie inaczej jest w wy padku budowli, pomieszczenia, rzeźby”. 
lub teoretykiem muzyki, socjologiem lub psychologiem muzyki, akustykiem, etnografem lub estetykiem itd., w każdej z tych dziedzin dokonując ponadto dalszego wyboru [...]”.

Problematyka poruszana w niniejszym artykule również sytuuje się na pograniczu kilku dziedzin, w szczególności muzykologii, literaturoznawstwa i studiów nad specyfiką języka muzycznego. Moim celem jest analiza środków, jakimi kompozytorzy starają się uzyskać pewien „efekt przestrzenności”, zarówno na poziomie samego tekstu muzycznego, jak i w zakresie elementów pozamuzycznych, dzięki którym muzyka zyskuje bardziej sugestywny charakter.

Zacznijmy od kilku ogólnych obserwacji na temat problemu przestrzeni w badaniach nad muzyką. Nie sposób ustalić jednej, wyczerpującej definicji pojęcia przestrzeni w muzyce ${ }^{2}$. W najogólniejszym ujęciu, przestrzeń jest, obok czasu, jedną z dwóch podstawowych kategorii niezbędnych do istnienia dzieła muzycznego - zarówno do jego tworzenia, jak i do jego wykonywania i odbioru. Badacze, świadomi trudności wynikających ze złożoności pojęcia przestrzeni w muzyce, unikają formułowania ogólnej definicji; zamiast tego proponują klasyfikacje rodzajów przestrzeni stanowiących przedmiot analizy muzykologów i teoretyków muzyki. Przyjrzyjmy się niektórym z proponowanych typologii.

Polony (2007: 9-10) wprowadza rozróżnienie na cztery rodzaje przestrzeni dźwiękowo-muzycznej: są to przestrzeń akustyczna („fizyczna przestrzeń dźwiękowa”, do pomiaru której wykorzystuje się specjalistyczne urządzenia), słuchowa (przestrzeń percepcji dzieła muzycznego, czyli „doznania przestrzeni ujawniające się w akcie słuchania”), muzyczna (wewnętrzna struktura dzieła muzycznego) oraz symboliczna lub mityczna, którą badacz opisuje jako

sferę przestrzennych wyobrażeń, przedstawień i asocjacji, a także pewnych przestrzennych idei, motywów i tematów literackich, ujawniajacych się w utworze muzycznym takich, jak np. źródło, rzeka, morze, góry, wẹdrówka, wschód i zachód słońca, i wiele innych (Polony 2007: 10).

Bardziej rozbudowaną klasyfikację rodzajów przestrzeni przedstawia Szymańska-Stułka (2015: 49). Badaczka wychodzi od podstawowego rozróżnienia dwóch pojęć, którymi są: przestrzeń przyrody, będąca przedmiotem dociekań kosmologii, filozofii przyrody i nauk ścisłych, oraz przestrzeń człowieka, czyli obszar zjawisk związanych z doświadczaniem przez niego otaczającego świata. W kolejnym etapie wyróżnia trzy pary przeciwstawnych kategorii; są nimi: przestrzeń dana i tworzona (sfera, w której sztuka istnieje, oraz ta, którą stwarza), przestrzeń zewnętrzna i wewnętrzna utworu (przestrzeń „otaczająca” dzieło muzyczne i jego

${ }^{2}$ Niektórzy badacze (por. Scruton [2009], Tarasti [2009], Wa silewska-Chmura [2011]) traktują pojęcie „przestrzeń muzyczna” jako synonim „przestrzeni w muzyce” („musical space” i „space in music” w pracach anglojęzy cznych), podczas gdy Polony (2007)i Szy mańska-Stułka (2015) stosują je jedy nie na określenie jednej z kategor ii przestrzeni w propon owanych przez siebie klasyfikacjach. 
Katarzyna Ptaczek: Między dźwiękiem, stowem i obrazem: o

przestrzenności $w$ muzyce

struktura wewnętrzna) oraz przestrzeń realna i wyobrażona (przestrzeń będąca zauważalnym, uchwytnym przez odbiorcę „medium formy” oraz obszar przestrzennych zjawisk, które zachodzą w wyobraźni zarówno twórcy, jak i odbiorcy). Zatrzymajmy się na chwilę przy tej ostatniej.

Badaczka charakteryzuje przestrzeń wyobrażoną jako „przestrzeń wizji, espaces imaginaires ${ }^{3}$, obszar odczucia, odkrywania nowych światów, artystycznej kreacji” (Szymańska-Stułka 2015: 49). Jest to zatem kategoria, która zawiera $\mathrm{w}$ sobie elementy przestrzeni symbolicznej lub mitycznej wyróżnionej przez Polonego, lecz nie jest z tym pojęciem tożsama - jej zakres wykracza bowiem poza sferę przestrzennych wyobrażeń wywoływanych przez muzykę w trakcie aktu odbioru. Dotyczy ona ogółu zjawisk, w które zaangażowana jest ludzka wyobraźnia, przez co odnosi się zarówno do odbioru muzyki, jak i do jej tworzenia.

Muzyka jest, bez wątpienia, sztuką, której odbiór uaktywnia zarówno zmysły, jak i wyobraźnię. Sposób, w jaki się jej doświadcza, zależy od wielu czynników, w szczególności od wrażliwości słuchacza, rozumianej jako ogólna zdolność do odczuwania emocji, od otwartości na intensywność przeżycia estetycznego, jakim jest odbiór dzieła muzycznego, oraz od okoliczności, które temu aktowi towarzyszą - doświadczenie kompozycji wykonywanej na żywo ma wszak zupełnie inny charakter niż odbiór tego samego dzieła utrwalonego na płycie lub innym nośniku. Percepcja dzieła muzycznego uwarunkowana jest również zdolnością słuchacza do odczytania treści „ukrytych” pod warstwą dźwięków i współbrzmień. Ta zaś jest tym większa, im bogatsze są doświadczenia odbiorcy $\mathrm{w}$ obcowaniu $\mathrm{z}$ muzyką i jego wiedza na temat specyfiki języka muzycznego, gdyż jest on formą komunikacji wykorzystującą określone schematy i kody.

Zatrzymajmy się na chwilę przy tej kwestii. Struktura języka muzycznego jest przedmiotem rozważań licznych prac naukowych. Choć użycie pojęcia ,język muzyczny" w odniesieniu do ogółu środków muzycznych, którymi kompozytorzy posługują się w swoich dziełach, na stałe zakorzeniło się w tradycji tekstów krytycznomuzycznych, większość badaczy jest zgodna co do tego, że „mowa dźwięków” (Harnoncourt 1995) nie jest językiem sensu stricto. Niemniej, muzyka, podobnie jak język, stwarza możliwość konstruowania logicznego dyskursu, również za sprawą środków wyrazu, takich jak figury retoryczne, tropy (np. metafora) i toposy, którymi się posługuje. To te właśnie wytworzone przez kulturę i tradycję $\mathrm{i}$ utrwalone $\mathrm{w}$ nich sposoby przedstawiania rzeczywistości kształtują, przynajmniej częściowo, wyobrażenia przestrzenne wywoływane przez muzykę. Ich obecność w języku muzycznym potwierdza

3 Kursy wa autorki cy towany ch słów. 
słuszność idei pojmowania całej kultury jako tekstu stworzonego z różnorakich produktów twórczej aktywności ludzkiej4.

Mając na uwadze tę właśnie wspólnotę środków wyrazu, Tarasti (2008: 22) wprowadza $w$ swojej pracy pojęcie toposu muzycznego, który, jak wyjaśnia, służy do wyrażenia $\mathrm{w}$ warstwie dźwiękowej pewnych pozamuzycznych treści. Podobną definicję proponuje Arnold (2002: 241), zdaniem którego

[t]oposy [...] to muzyczne „miejsca” albo „punkty” stylu: zestawy melodycznych, harmonicznych, rytmicznych, teksturalnych, instrumentalnych i właściwych akom paniamentowi gestów, które wywołują skojarzenia z określoną klasą czy grupą ludzi, z fizycznym umiejscowieniem, stanami umysłu i działaniami społecznymis.

Toposy muzyczne odegrały szczególną rolę w kompozycjach okresu romantyzmu. Wynikała ona $\mathrm{z}$ zacieśnienia się relacji między muzyką i innymi dziedzinami sztuki, zwłaszcza literaturą i malarstwem. Kompozytorzy okresu romantyzmu posługiwali się toposami zaczerpniętymi z poprzednich epok, wytworzyli też własne, które częściowo utrwaliły się w tradycji. Twórcą, który szczególnie chętnie sięgał po takie środki wyrazu, był Ferenc Liszt. W jego kompozycjach odnajdujemy m.in. pytanie faustyczne, wyrażane, jak wyjaśnia Tarasti (2008: 23), za pomocą melodii o kierunku wznoszącym, której dążenie zostaje przerwane przed dotarciem do punktu kulminacyjnego. Jak za chwilę zobaczymy, kompozytor posługiwał się także toposem wiejskiego (pastoralnego) krajobrazu, przywoływanego za pośrednictwem określonych efektów brzmieniowych i harmonicznych oraz dodatkowych odniesień typowych dla muzyki programowej.

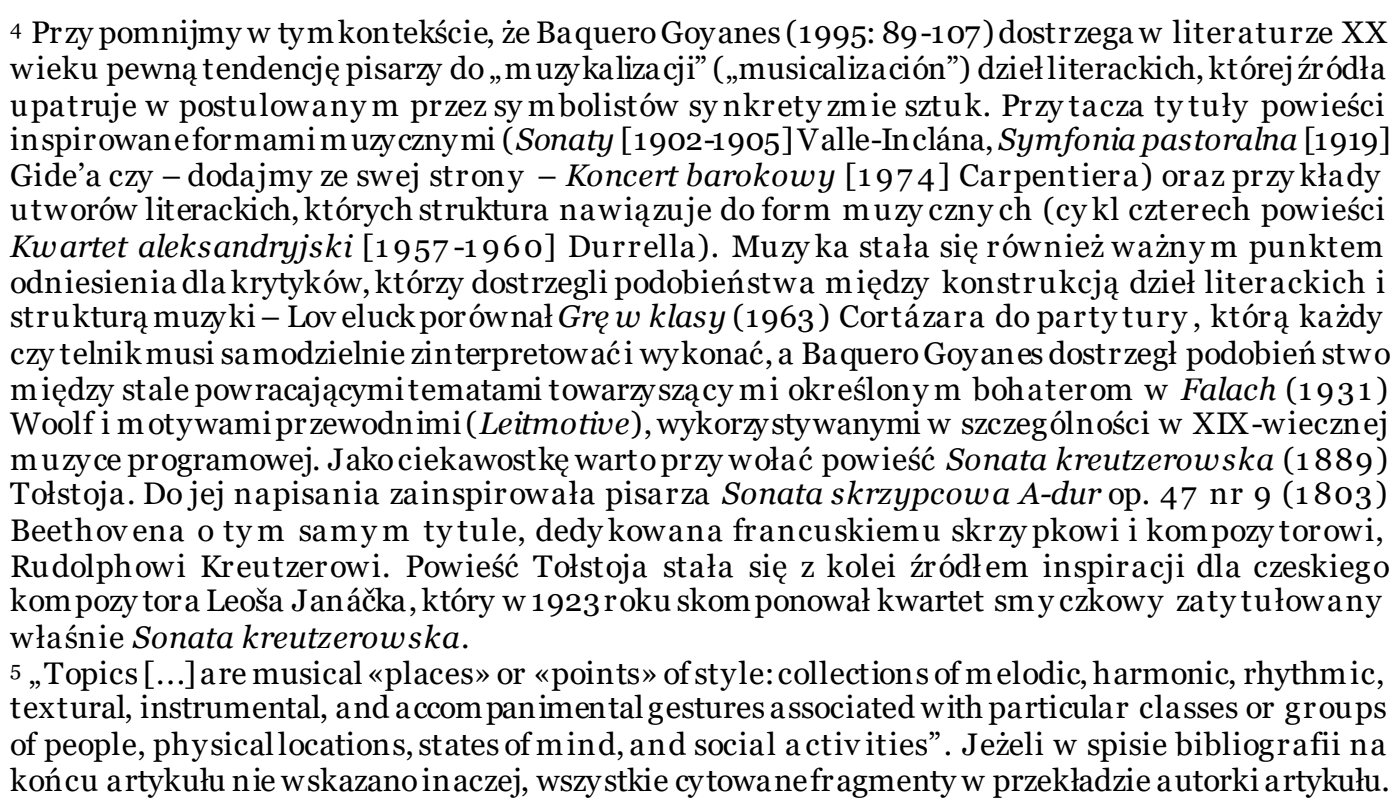


Katarzyna Płaczek: Między dźwiękiem, słowem i obrazem: o

przestrzenności $w$ muzyce

\section{Literackość i ilustracyjność przestrzeni w muzyce programowej XIX wieku}

Do XIX wieku dominująca formą przekazu muzycznego była muzyka absolutna, wolna od wszelkich eksplicytnych odniesień do rzeczywistości pozamuzycznej i, tym samym, pozostawiająca wykonawcy i odbiorcy największą swobodę interpretacji. W opozycji do muzyki absolutnej znajduje się, z jednej strony, muzyka ilustracyjna, której celem jest zobrazowanie za pomocą muzycznych środków pewnych zjawisk (głównie tych zachodzących w przyrodzie), oraz, $\mathrm{z}$ drugiej strony, muzyka programowa. Odsyła ona odbiorcę do konkretnych przestrzeni rzeczywistych lub literackich - za pomocą tytułu, niekiedy uzupełnionego komentarzem kompozytora, wyrażających różnorakie treści pozamuzyczne, czyli program. To tutaj właśnie twórcy najczęściej odwołują się do wyobrażeń przestrzennych wypracowanych i skonwencjonalizowanych przez tradycję kulturową, szczególnie literacką, co nadaje muzyce programowej charakter intertekstualny. Ową szczególną specyfikę zawdzięcza ona idei korespondencji sztuk - w jej myśl elementy innych dziedzin sztuki, w szczególności literatury i malarstwa, przeniknęły do muzyki po tym, jak stały się źródłem inspiracji dla twórców zarówno w planie treści, jak i formy. Najwięcej przykładów dostarcza w tym obszarze muzyka symfoniczna, na którą nurt programowości miał znaczący wpływ w 2. połowie XIX i 1. połowie XX wieku - wystarczy wspomnieć w tym miejscu dzieło Co słychać $w$ górach (Ce qu'on entend sur la montagne, 1848) Ferenca Liszta, uznawane za pierwszy $w$ historii poemat symfoniczny ${ }^{6}$, i cykl 6 poematów symfonicznych Moja ojczyzna (Má vlast) Bedřicha Smetany (1872-1879)7. Zatrzymajmy się na chwilę przy tym ostatnim dziele.

By uzyskać interesujący nas „efekt przestrzenności”, Smetana wykorzystuje różne techniki, zarówno muzyczne, jak i pozamuzyczne. Po pierwsze, nadaje wszystkim poematom tytuły, które odsyłają do określonych przestrzeni zajmujących ważne miejsce w czeskiej tradycji wyjątkiem jest trzecia część, Sárka, opowiadająca historię postaci o tym właśnie imieniu, bohaterki znanej czeskiej legendy. Kompozytor sięga również po tzw. technikę motywów przewodnich, w której „dany motyw lub temat jest powiązany $\mathrm{z}$ określoną pozamuzyczną ideą i pojawia się zawsze jako jej nośnik" (Michels 1995: 129) ${ }^{8}$. W poematach symfonicznych

\footnotetext{
6 Utwór Liszta powstał na podstawiepoem atu Victora Hugo oty m samy m ty tule, pochodzącego z wy danego w 1831 roku tomiku poezji Liście jesienne (Les Feuilles d'automne), i jest jednym z wielu poem atów sy m foniczny ch odsy łający ch do konkretnego tekstu literackiego, podobnie jak, na przy kład, Tako rzecze Zaratustra (1896) i Don Kichot (1898) Richarda Straussa.

7 W analizie dzieła Sm etany wy kor zy stuję edy cję Boosey \& Hawkes (Sm etana 1950).

8 Zwróćmy uwagę na to, że choć pojęcie „motyw przewodni” powstało na gruncie muzyki, stanowiący jego podstawę termin „m oty w” wy wodzi się z dziedziny literaturoznawstwa.
} 
Smetany odnajdujemy zatem motyw wyszehradzkiego zamku, występujący zwykle wraz z motywem Wełtawy, nad którą leży owa twierdza, oraz mroczny motyw Białej Góry, przywodzący na myśl skojarzenia z krwawą bitwą - w 1620 roku armia Habsburgów pokonała w niej wojska czeskich protestantów. Drugą, najbardziej znaną część cyklu, zatytułowaną Weltawa, kompozytor charakteryzuje w następujących słowach:

Utwór ten opisuje bieg rzeki, począwszy od dwóch małych dopływów, jednego zimnego, drugiego ciepłego, aż do miejsca, w którym łączą się one w jeden wspólny nurt. Rzeka płynie przez lasy i łąki, przez urokliwe wiejskie okolice, gdzie obchodzone są radosne święta. Rusałki tańczą w blasku księżyca, a z pobliskich skał wyłaniają się ruiny zamków, dumnie wznoszące się ku niebu. Wełtawa przechodzi, kłębiąc się, w Svatojánské proudy, później zaś szerokim korytem zmierza w stronę Pragi, opływając Wyszehrad, by majestatycznie zniknąc na horyzoncie i wpłynąć do Łaby (cyt. przez Kregor 2015: 233)9.

Smetana zamieszcza w partyturze podtytuły, które ułatwiają wykonawcy przekazanie treści kompozycji, lecz nie są one potrzebne słuchaczowi - muzyka ma tak obrazowy charakter, że opis słowny wydaje się zbędny. Weltawę rozpoczynają wznoszące i opadające ruchy szesnastkowe, początkowo w partiach fletów, później również klarnetów. Tuż potem rolę instrumentów dętych przejmują drugie skrzypce, altówki i wiolonczele. Ciemna barwa tych instrumentów i kontrastujące $\mathrm{z}$ nią subtelne brzmienie fletów obrazują dwa górskie dopływy rzeki - Zimną i Ciepłą Wełtawę, o których mówi Smetana w zacytowanym powyżej fragmencie. Następnie w partii pierwszych skrzypiec pojawia się temat motyw Wełtawy - a pierwsze dwa motywy łączą się w jeden wspólny nurt. We fragmencie zatytułowanym Leśne polowanie (Lesni honba) na tle „rzecznych” motywów melodię prowadzą trąbki i waltornie, przywodzące na myśl brzmienie myśliwskich rogów. Kolejny fragment, Wiejskie wesele (Venkovská svatba), to marsz utrzymany w ludowym charakterze. W części zatytułowanej Blask księżyca. Taniec rusałek (Luna. Fej Rusalek) partie harfy i fletów utrzymują płynny nurt rzeki, a melodia skrzypiec naśladuje śpiew rusałek w wysokim rejestrze o „mieniącej się” barwie. Motyw Wełtawy powraca, lecz zostaje przerwany przez gwałtowny strumień szybkich dźwięków - to moment, w którym rzeka wpada do nieistniejącego już rwącego strumienia Svatojanské proudy, od którego nazwy pochodzi podtytuł tego fragmentu. Główny motyw powraca w kulminacji opatrzonej tytułem Szerokie koryto Wettawy (Slroký tok

\footnotetext{
9 „The composition depicts the course of the river, from its beginning where two brooks, one cold, the other warm, join a stream, running through for ests and meadows and a lov ely country side wherem erry feasts are celebrated; water-spites dance in the moonlight; on nearby rocks can be seen the outline of ruined castles, prou dly soaring into the sky. Vltava swirls th rough St. John Rapids and flows in a broad stream towards Prague. It passes Vyšehrad and disappears majestically into the distance, where it joins the Elbe".
} 
Katarzyna Płaczek: Między dźwiękiem, stowem i obrazem: o przestrzenności $w$ muzyce

Vltavy), a następnie wybrzmiewa majestatyczny Motyw Wyszehradu (Motív Vyšehradu); na koniec rzeka, a wraz z nią muzyka, stopniowa odpływają, znikając na horyzoncie.

Kompozytor wykorzystuje tu zatem dwie techniki. Po pierwsze, wprowadza tytuły odnoszące się do rzeczywistości pozamuzycznej. Prócz tego, stosuje różne środki w warstwie muzycznej - możemy nawet pokusić się o stwierdzenie, że niemal każdy element dzieła muzycznego ${ }^{10} \mathrm{w}$ Wettawie niesie pewne przestrzenne treści, niekiedy samodzielnie, niekiedy $\mathrm{w}$ połączeniu $\mathrm{z}$ innym składnikiem formotwórczym. Ruch $\mathrm{i}$ kierunek linii melodycznej ilustrują bieg (przestrzeń) rzeki, a zmiana oznaczenia taktowego z 6/8 na 2/4 w części zatytułowanej Wiejskie wesele nadaje muzyce ludowy charakter, właściwy wiejskiej scenerii; podobną rolę spełnia rytmika, charakterystyczna dla tańców ludowych ${ }^{11}$. Zmiany agogiczne (niewskazane przez kompozytora w zapisie nutowym, lecz będące naturalną konsekwencją modyfikacji metrum) pozwalają na przejście z szybkiego pulsu płynnego nurtu „rzecznych motywów” do nieco wolniejszego tempa tanecznych części. Z kolei dynamika i harmonika nadają kształt masywnej kulminacji, która obrazuje najszerszy odcinek rzeki. Wspomniane już efekty brzmieniowe (kolorystyczne) w początkowej części utworu niezwykle sugestywnie imitują odgłosy płynącej wody, a barwa myśliwskich rogów przenosi słuchacza na Leśne polowanie. Nie brak również wskazówek dotyczących artykulacji - w części, w której motyw Wełtawy powraca po Tańcu rusałek, kompozytor zamieszcza adnotację sempre ondeggiante (Smetana 1950: 58), sugerując tym samym, że charakter przebiegu (przestrzeni) linii melodycznej winien imitować fale na powierzchni rzeki.

Smetana wykorzystuje również tematy zaczerpnięte z czeskiej muzyki ludowej, za sprawą których słuchacze - o ile wystarczająco dobrze znają czeski folklor $-\mathrm{z}$ łatwością przenoszą się myślami do ojczyzny kompozytora. Tym środkiem posługuje się również Ferenc Liszt w swojej Fantazji romantycznej na temat dwóch melodï szwajcarskich (Fantaisie romantique sur deux mélodies suisses; 1835-36). Jednym z dwóch głównych tematów tej kompozycji jest parafraza Ranz-des-Vaches, którą Jean-Jacques Rousseau w swoim Stowniku muzycznym charakteryzuje tymi słowami: „popularna pieśń wśród Szwajcarów, grywana przez młodych pasterzy na cornamusie ${ }^{12}$ w czasie pilnowania zwierząt w

10 Elem enty dzieła muzy cznegoto części składowekom pozy cji muzy cznej porządkujące materiał dźwiękowy w czasie i przestrzeni. Wy różnia się osiem elem entów dzieła muzy cznego: ry tmika, m etrum, agogika, m elody ka, harmonika, dynamika i kolorystyka i artyk ulacja (por. Wójcik 1999:1516).

${ }^{11}$ 2/4 to oznaczenietaktowe niektórych czeskich tańców ludowy ch, m.in. polki i furianta, które poiawiają się w twórczości Smetany (obie formy wy korzy stał w operze Sprzedana narzeczona [1866]).

12 Dawny instrument dęty drewniany. 
górach13" (Rousseau 1768: 405). Zajmuje ona szczególne miejsce w szwajcarskiej tradycji, gdyż, jak opisuje Zwinger w traktacie Fasciculus Dissertationum Medicarum Selectiorum z 1710 roku, szwajcarscy żołnierze przebywający poza krajem, gdy tylko słyszeli jej dźwięki, odczuwali tak silną tęsknotę za ojczyzną, że decydowali się na dezercję $\mathrm{i}$ powrót do Szwajcarii (por. Schmid 2010). Ta właśnie tęsknota - mal du pays - znalazła się w podtytule drugiego tematu, który Liszt wykorzystuje w swoim dziele. Nostalgiczny i jednocześnie dramatyczny charakter tego tematu w bardzo sugestywny sposób oddaje uczucia, o których pisze Zwinger, będące esencją szwajcarskiej tradycji romantycznej. Stosując muzyczną parafrazę, przypisując tematom tytuły i nasycając muzykę melancholią, Liszt przenosi słuchacza (i wykonawcę) w szwajcarskie Alpy. Warto w tym miejscu przypomnieć, jak ważną rolę w literackiej tradycji oświecenia i romantyzmu pełni alpejski krajobraz - wystarczy przywołać poemat Die Alpen (1732) Albrechta von Hallera, dzieła Słowackiego i Byrona (por. Lafond-Kettlitz 2009 i Roger 2007).

Motywy Ranz-des-Vaches i mal du pays pojawiają się również w Latach pielgrzymstwa (Années de pèlerinage) Liszta, trzech zbiorach miniatur fortepianowych zebranych $\mathrm{w}$ jednym albumie, powstałych $\mathrm{w}$ latach 1835-1842. Ich tytuły to kolejno: Pierwszy rok. Szwajcaria (Première Année. Suisse), Drugi rok. Wtochy (Deuxième Année. Italie) i Trzeci rok (Troisième Année). Omówię teraz pierwszą suitę, gdyż jest ona jednym z najbardziej reprezentatywnych przykładów dzieł, w których kompozytor uzyskuje „efekt przestrzenności”, łącząc dźwięk, słowo i obraz.

Pierwszy rok. Szwajcaria ukazał się nakładem niemieckiego wydawnictwa Schott w 1855 roku, w formie bardzo zbliżonej do tej, na której opierają się współczesne edycje. Należy jednak pamiętać, że znaczna część utworów wchodzących w skład zbioru została wydana wcześniej, w nieco innych opracowaniach: $w$ zredagowanym przez paryskie wydawnictwo Richault w 1840 roku zeszycie również noszącym tytuł Pierwszy rok. Szwajcaria oraz w wydanym dwa lata później przez wiedeńskie wydawnictwo Haslinger Albumie podróżnika (Album d'un voyageur). Jak zauważa Nowik (2015: 139), tytuł tego ostatniego zbioru przywołuje szczególnie żywą w epoce romantyzmu ideę człowieka wędrowca. Dodajmy przy tym, że tytuł Lata pielgrzymstwa (tłumaczony również jako Lata wędrówek) nawiązuje, jak możemy się domyślać, do powieści Lata wędrówki Wilhelma Meistra (Wilhelm Meisters Wanderjahre; 1821) Goethego i do poematu Wędrówki Childe Harolda (Childe Harold's Pilgrimage; 1809-1818) Byrona. W przedmowie do wydania Albumu wędrowca z 1842 roku Liszt tak pisze o swoim dziele:

Po odbyciu w ostatnim czasie wielu podróży do nowych krajów, poprzez różne krajobrazy i miejsca uświęcone przez historię i poezję, po tym, jak poczułem, że różnorodne zjawiska przyrody i procesy mające w niej miejsce nie przesunęly się przed moimi oczami jako puste

\footnotetext{
13 „Air célèbre parmi les Su isses, \& que leurs jeunes Bouviers jou ent sur la Cornemuse en gardant le bétail dans les montagnes".
} 


\title{
Katarzyna Płaczek: Między dźwiękiem, słowem i obrazem: o przestrzenności $w$ muzyce
}

\begin{abstract}
obrazy, lecz głęboko poruszyły moją duszę, że nawiązała się między nami niejasna, lecz natychmiastowa więź, nieokreślony, lecz prawdziwy związek, niewytłumaczalne, ale niewątpliwe porozumienie - starałem się pokazać za pomocą muzyki niektóre $\mathrm{z}$ moich najsilniejszych odczuć $\mathrm{i}$ najgłębiej przeżytych wrażeń (Solyok \& Mező 1976: X)14.
\end{abstract}

Wrażenia, które opisuje, zrodzily się w czasie jego pobytu w Szwajcarii w latach 1835-36. W Pierwszym roku swe odczucia wyraża nie tylko za pomocą muzyki, ale również za pośrednictwem dołączonych do zapisu nutowego cytatów zaczerpniętych $\mathrm{z}$ różnych utworów literackich. W wydaniu Schotta z 1855 roku pojawiają się także ilustracje Roberta Kretschmera (1812-1872), niemieckiego malarza i rysownika. Uzupełnienie zapisu nutowego tekstem słownym i obrazem pozwala dookreślić przestrzenie, do jakich ma odsyłać muzyka, choć ta, nawet bez pozamuzy cznych środków, ma bardzo sugestywny charakter.

Cykl Pierwszy rok. Szwajcaria składa się z 9 części. W wydaniu z 1855 roku jedynie dwie $\mathrm{z}$ nich - Krajobraz wiejski (Pastorale), również nawiązujący tytułem do utwierdzonych przez tradycję kulturową i literacką obrazów, oraz Genewskie dzwony (Les cloches de Genève) - nie zostały opatrzone literackim komentarzem ${ }^{15}$. Dobór cytatów, które kompozytor zamieszcza przy kolejnych utworach, z pewnością jest nieprzypadkowy, tak samo jak dobór autorów cytowanych tekstów: Byron, Senancour i Schiller to postaci związane ze Szwajcaria nie tylko poprzez swoje biografie, ale przede wszystkim przez swoją twórczość. Pierwszy utwór w zbiorze to Kaplica Wilhelma Tella (Chapelle de Guillaume Tell), zaopatrzony w motto: „Jeden za wszystkich, wszyscy za jednego” („Einer für Alle - Alle für Einen”; Liszt, 1855: I). Majestatyczny i triumfalny charakter akordów otwierających dzieło przywodzi na myśl postać legendarnego szwajcarskiego bohatera narodowego, a wykorzystana przez Liszta do skomponowania tej chorałowej sekwencji szwajcarska melodia ludowa, grywana przez pasterzy na alpejskich rogach, maluje przed słuchaczem krajobraz podobny do tego, jaki widzimy na ilustracji Kretschmera.

Kolejna część nosi tytuł Nad jeziorem Wallenstadt (Au lac de Wallenstadt) i jest, zdaniem Arnolda (2002: 79), „jednym z najlepszych wodnych utworów Liszta” (,one of his [...] best water pieces”).

\footnotetext{
14 „Having in recent times travelled in many new countries, through different lan dscapes and places consecr ated by history and poetry, having felt that the varied phen omena of nature, the processes taking place in nature, did not pass before my eyes as empty images but produced deep em otions in my soul, and that between us a vague but imm ediate relationship had established itself, and undefined but real rapport, an in explicable but ir refutablecommunication - I have tried to present in music some of my strongest sensations and my most lively impressions".

15 Natomiast w Albumie podróżnika do ostatniej części, Genewskie dzwony, dołączony został fragment wspomnianego już poematu Wędrówki Childe Harolda By rona.
} 
Rzeczywiście, jest to niezwykle sugestywna kompozycja: rozłożone akordy w ruchu szesnastkowym w partii lewej ręki obrazują spokojną taflę jeziora, a melodia prowadzona $\mathrm{w}$ partii prawej ręki, o kierunku na przemian wzrastającym i opadającym, imituje delikatne fale i podmuchy wiatru muskającego powierzchnię wody. Spokojny i „czysty” charakter muzyki Liszta wybrzmiewa również we fragmencie Wędrówek Childe Harolda, dołączonym do tej części:

[Z] światem, w którym żyję,

$\mathrm{Z}$ jego burzami sprzeczne wody twoje

Każą tą ciszą, którą głąb ich kryje,

Zmienić wir ziemi na czyściejsze zdroje (Byron 1955:

$173)^{16}$.

W części trzeciej, zatytułowanej Krajobraz wiejski, Liszt wprowadza parafrazę wspomnianego już motywu Ranz-des-Vaches. Pojawia się on na zmianę z prostą melodią o pogodnym charakterze, która przez swój koloryt przywodzi na myśl brzmienie fletów. Towarzyszy jej akompaniament w postaci rozłożonych melodycznie interwałów, wśród których dominują kwinta czysta i oktawa, charakterystyczne dla muzyki ludowej17. Kompozytor nie opatrzył tej części żadnym literackim komentarzem, lecz jest ona nie mniej sugestywna niż pozostałe. Dzieje się tak dlatego, że Liszt posługuje się wspomnianym wcześniej muzycznym toposem krajobrazu wiejskiego, czyli pewnym skonwencjonalizowanym sposobem muzycznego przedstawiania wiejskiej przestrzeni18.

Po sielskim Krajobrazie wiejskim następuje czwarta część, Nad brzegiem źródła (Au bord d'une source), kolejna, po Nad jeziorem Wallenstadt, „wodna” miniatura w cyklu. Na stronie tytułowej z ilustracją Kretschmera widnieje fragment wiersza Der Flüchtling Schillera:

W delikatnym chłodzie

Natura zaczyna

Swe poranne zabawy (Liszt 1855: IV) ${ }^{19}$.

\footnotetext{
16 ,[T] hy contrasted lake / With thewild world I dwell in, is a thing / Which warns me, with its stillness, to forsake / Earth's troubled waters for a purer spring" (Liszt 1855: II).

17 Przy pomnijmy, że interwał kwinty w partiach altówek i wiolonczel otwiera również Symfonię pastoralna Beethovena.

${ }_{18} \mathrm{Na} u$ uagę zasługuje także dobór tonacji - E-dur. Może on zaskakiwać, gdy ż, zdaniem Moore’a, autora Complete Encyclopedia of Music (1854), „[t]he major of E natural is bright and pellucid, a dapted to the m ost brilliant subjects" (cyt. pr zez Ishiguro $2010: 44$ ). Podobnego zdania jest Pau er (1876:24), teor etyk muzyki współczesny Lisztowi, według którego „E major, the brightest and most powerful key, expresses joy, magnificence, splendour, and the highest brilliancy”. Bardziej zrozumiały wy dawałby się zatem wy bór tonacji $G$-dur, w której Liszt napisał pierwszą wersję Krajobrazu wiejskiego - Allegro pastorale z Albumu podróżnika. Franz Schubert, jeden z prekursorów romantyzmu w muzy ce, tak pisał o tonacji G-dur: „Ev ery thing rustic, idy llic and ly rical, every tender gratitude for true friendship and faithful love, in a word, ev ery gentle and peacefulemotion of the heart is cor rectly expressed by this key" (cyt. przez Ishiguro 2010: 33). 19 „In säuselnder Kühle / Beginnen die Spiele / Der jungen Natur“.
} 
Katarzyna Płaczek: Między dźwiękiem, stowem i obrazem: o

przestrzenności $w$ muzyce

Wyłaniająca się z gęstej faktury melodia ma żartobliwy charakter, nieco podobny do tego, który cechuje temat z poprzedniej części, a subtelny akompaniament w partii lewej ręki naśladuje delikatne podmuchy wiatru, o których pisze Schiller. Utwór ten, jak i towarzysząca mu ilustracja, wywołują skojarzenia $\mathrm{z}$ locus amoenus, literacką przestrzenią skonwencjonalizowaną chyba w stopniu najwyższym z możliwych.

Kolejna część, Burza (Orage), przełamuje wizerunek pogodnego szwajcarskiego krajobrazu. Chromatyczne pochody oktawowe o gwałtownym charakterze i burzliwe tremolo przywodzą na myśl utrwalony w literaturze i wspomnieniach pierwszych alpinistów obraz nieprzyjaznego, wręcz przerażającego alpejskiego pejzażu. Liszt załącza do Burzy następujący cytat z poematu Byrona:

Ale powiedzcie [niebiosa, turnie, rzeki i jeziora], gdzie wasze granice?

Czyście jak burza, co człeka rozpiera?

Czy lot wasz, jak lot orłów, do gniazda dociera?20 (Byron 1955: 177)

Dolina Obermanna (Vallée d'Obermann), miniatura o wiele bardziej rozbudowana niż poprzednie części pierwszego zeszytu Lat pielgrzymstwa, odznacza się też najbardziej epickim charakterem. Jej tytuł - również „przestrzenny” - nawiązuje do powieści Obermann (1804), autorstwa francuskiego pisarza Étienne'a Piverta de Senancour, której akcja rozgrywa się w Szwajcarii. Tytułowa postać tego dzieła to bohater romantyczny, który, znużony życiem, udaje się w Alpy, by tam odnaleźć sens egzystencji. Jak zauważa Arnold (2002: 80),

Dolina Obermanna to jedno z pierwszych obszernych jednoczęściowych dzieł fortepianowych, w których kompozytor stara się wyrazić za pomocą muzyki literacki zamysł. Kompozytor / pianista staje się Obermannem i poprzez fortepian, który pełni rolę nośnika, bohater doświadcza wszechogarniających, nieprzeniknionych sił Natury ${ }^{21}$.

W wydaniu Schotta Liszt dołącza do tej części aż trzy cytaty - dwa pierwsze pochodzą z powieści Senancoura, a ostatni z Wędrówek Childe

\footnotetext{
20 „But where of y e, oh tempests, is the goal / Are you like those within thehuman breast? / Or do ye find, at length, like eagles, some high nest?” (Liszt 1855: V)

21 „Vallée d'Obermann is one of the earliest single-movement large scale piano works intended to express literary conceit musically. The com poser/pianist becomes Obermann, and through the piano, which act as conduit, the hero experiences the overwhelming, unpenetrable [sic] forces of Nature".
} 
Harolda Byrona ${ }^{2}$. W pierwszym cytowanym przez kompozytora fragmencie Obermanna, bohater zastanawia się: „Czego pragnę? Czym jestem? Czego oczekiwać od natury?”23 (Liszt 1855: VI), wpisując swe poszukiwania w ogólną przestrzeń spotkania człowieka z naturą, która, jak zobaczymy, z czasem przybierze formę górskiego krajobrazu. Echa tych pytań, coraz bardziej niecierpliwych, słyszymy w początkowym fragmencie dzieła, w którym temat, wyeksponowany w pierwszej frazie, nieustannie powraca, raz w najwyższym, raz w najniższym głosie. Kolejny fragment dzieła Liszta zdaje się łączyć z drugim cytatem z powieści Senancoura, w którym Obermann stwierdza:

Niewysłowiona wrażliwość, urok i udręka daremnych lat; rozległa świadomość zawsze przytłaczającej i zawsze niezbadanej natury, wszechobecna namiętność, obojętność, głęboka mądrość [...]; wszystkie potrzeby i dojmujące frasunki, które zawrzeć się mogą w śmiertelnym sercu, wszystko to poczułem, wszystkiego tego doświadczyłem tamtej pamiętnej nocy”24 (Liszt 1855: VI).

Faktura utworu coraz bardziej zagęszcza się, przez co stale powracający temat staje się bardziej dramatyczny i „przytłaczający”, i tym samym zaczyna przypominać górski krajobraz na ilustracji Kretschmera. Wzrastające napięcie prowadzi wreszcie do dramatycznej kulminacji. Nie następuje po niej jednak spodziewane rozładowanie emocji - fraza niespodziewanie urywa się, a utwór pozbawiony jest oczekiwanego epilogu.

Ostatnie części Pierwszego roku to Egloga (Églogue), również odsyłająca do literackiej, mocno skodyfikowanej przestrzeni, oraz Le mal du pays (Tęsknota za krajem) i nokturn Genewskie dzwony, stanowiący zamknięcie całego cyklu.

Ilustracje towarzyszące zapisowi nutowemu, cytaty z dzieł literackich, komentarze Liszta, nawiązania do tradycji i historii Szwajcarii - wszystko to sprawia, że słowo i obraz odgrywają ważną rolę w Pierwszym roku. Szwajcarï. Dzięki zastosowaniu szeregu technik i środków muzycznego przekazu, kompozytor „przenosi” słuchacza do określonych przestrzeni i oddaje charakter wybranych miejsc w niezwykle sugestywny dla odbiorcy sposób. Rola, jaką w jego kompozycji odgrywają słowo i obraz, dowodzi istnienia pewnej wspólnej dla wszystkich odbiorców sztuki przestrzeni, którą jest przestrzeń kultury, stanowiąca sieć wzajemnie przenikających się, mniej lub bardziej skodyfikowanych obrazów rzeczywistości.

\footnotetext{
${ }^{22}$ Cytat ten nie pojawia się w pierwszej wersji Doliny Obermanna, zamieszczonej w Albumie podróżnika.

23 "Que v eux-je? que suis-je? que demander à la nature?"

24 „In dicible sen sibilité, charme et tourment de nos v aines années; v aste conscience d'une nature partout a ccablante et partout impénétrable, passion universelle, in différence, sagesse avancée [...]; tout ce qu'un m ortel peut contenir de besoin set d'ennuis profonds, j'ai tout senti, tout éprouvé dans cette nuit mém orable".
} 


\section{Katarzyna Płaczek: Między dźwiękiem, słowem i obrazem: o przestrzenności $w$ muzyce}

Niemniej, w muzyce zawsze najważniejszy jest dźwięk, gdyż, jak stwierdziła Martha Argerich, „[m] uzyki trzeba słuchać, nie da się o niej mówić. Słowa tego nie oddadzą [...]. [Muzyka] wymyka się słowom" (Argerich 2014).

\section{Bibliografia}

Agawu, V. K. 1991. Playing with Signs. A semiotic interpretation of classical music. Princeton, New Jersey: Princeton University Press. @: https://is.muni.cz/el/1421/podzim2007/VH_53/Agawu_Playing_with_Signs. pdf?lang=en;zpet $=\% 2$ Fvyhledavani\%2F\%3Fsearch\%3Dkosmologie\%20agenda :th\%26start\%3D6

Arnold, Ben. 2002. The Liszt Companion. Westport: Greenwood Press.

Baquero Goyanes, M. 1995. Estructuras de la novela actual. Madryt: Castalia.

Bloody daughter [film]. 2014. Reż. Stéphanie Argerich. Francja: Intermezzo films.

Byron, G. G. B. 1955. Wędrówki Childe Harolda. Dramaty. Przekł. J. Kasprowicz. Warszawa: Państwowy Instytut Wydawniczy.

Eggebrecht, H. H. 1992. Muzyka i czas. w: Dahlhaus, C., Eggebrecht, H. H. Co to jest muzyka? Przekł. D. Lachowska. Warszawa: Państwowy Instytut Wydawniczy. 160-164.

Harnoncourt, N. 1995. Muzyka mową dźwięków. Przekł. M. Czajka. Warszawa: Ruch Muzyczny.

Harnoncourt, N. 1999. Dialog muzyczny: rozważania o Monteverdim, Bachu $i$ Mozarcie. Przekł. M. Czajka. Warszawa: Ruch Muzyczny.

Ishiguro, M. A. 2010. The affective properties of keys in instrumental music from the late nineteenth and early twentieth centuries (rozprawa doktorska). University of Massachusetts Amherst. http://scholarworks.umass.edu/cgi/viewcontent.cgi?article $=1561 \&$ context $=$ th eses

Kregor, J. 2015. Program music. Cambridge: Cambridge University Press. @: https://books.google.pl/books?id=rqwPBgAAQBAJ\&printsec $=$ frontcover\&hl= $\mathrm{pl} \# \mathrm{v}=$ onepage\&q\&f$=$ false

Lafond-Kettlitz, B. 2009. Die Alpen in Literatur und Malerei. Albrecht von Haller, Caspar Wolf, Ludwig Hohl, Ferdinand Hodler. w: Études Germaniques, 4 (256). Klincksieck. @: https://www.cairn.info/revue-etudes-germaniques2009-4-page-933.htm

Langer, S. 1953. Feeling and Form. A Theory of Art. Nowy Jork: Charles Scribner's Sons.

@: https://monoskop.org/images/1/11/Langer_Susanne_K_Feeling_and_Form A_Theory_of_Art.pdf

Lissa, Z. 1974. Wstęp do muzykologii. Warszawa: Polskie Wydawnictwo Naukowe.

Liszt, F. 1855. Années de pèlerinage.Première Année. Suisse. Mainz: Schott. @: http://imslp.nl/imglnks/usimg/2/21/IMSLP13834-Liszt_-

_S160_Ann\%C3\%A9es_de_P\%C3\%A8lerinage_1\%C3\%A8re_Ann\%C3\%A9e No1-5_(Schott).pdf, $\quad$ http://imslp.nl/imglnks/usimg/d/dd/IMSLP13835Liszt_- 
_S160_Ann\%C3\%A9es_de_P\%C3\%A8lerinage_1\%C3\%A8re_Ann\%C3\%A9e_ No6-9_(Schott).pdf

Losiak, R. 2005. Doświadczenie odbioru muzyki w świetle fenomenologii percepcji Maurice'a Merleau-Ponty'ego. Muzyka, 1. 87-115.

Losiak, R. 2012. Muzyka bliżej ciała. Wokół problemu percepcji muzycznej. w: Acta Universitatis Wratislaviensis, 3426. 149-162. @: pkult.sjol.eu/download.php?id=4727d23aaa8265e6b52448f428b6928965ofe1 54

Michels, U. 1995. Atlas muzyki, t. I. Przekł. P. Maculewicz. Warszawa: Pruszyński i S-ka.

Nowik, W. 2015. Ku uniwersalizmowi sztuk - Franciszek Liszt. «Lata pielgrzymki. Rok drugi. Włochy». Polski Rocznik Muzykologiczny 2015. 139154. http://www.zkp.org.pl/files/IwonkaL/Polski\%2oRocznik\%2oMuzykologiczny /PRM_2015_Nowik.pdf

Okoński, M. 2013. O obszarach muzycznej czasoprzestrzeni w twórczości chóralnej a capella Andrzeja Koszewskiego. Bydgoszcz: Wydawnictwo Uniwersytetu Kazimierza Wielkiego w Bydgoszczy. @: http://repozytorium.ukw.edu.pl/bitstream/handle/item/1430/Marta\%20Oko nski\%20O\%20obszarach\%20muzycznej\%20czasoprzestrzeni\%20w\%20tworcz osci\%20choralnej\%20a\%20cappella.pdf?sequence $=1$

Pauer, E. 1876. The Beautiful in Music. Londyn: Novello. @: https://ia802505.us.archive.org/34/items/elementsofthebea010421mbp/ele mentsofthebea010421mbp.pdf

Polony, L. 2007. Przestrzeń i muzyka. Kraków: Akademia Muzyczna w Krakowie.

Roger, A. 2007. Breve tratado del paisaje. Madryt: Biblioteca Nueva.

Rousseau, J. J. 1768. Dictionnaire de musique. Paryż: Chez la veuve Duchesne. @: $\quad$ http://imslp.nl/imglnks/usimg/e/e5/IMSLP72006-PMLP144356Dictionnaire_de_musique_(1768).pdf

Schmid, C. 2010. Historisches Lexikon der Schweiz. @: http://www.hls-dhsdss.ch/textes/d/D17439.php

Scruton, R. 2009. Understanding music. Philosophy and interpretation. Londyn, Nowy Jork: Continuum. @: https://portalconservador.com/livros/RogerScruton-Understanding-Music1.pdf

Smetana, B. 1950. Die Moldau. Symphonic poem. Londyn: Boosey \& Hawkes.

Solyok, I., Mező, I. 1976. Preface. w: Ferenc Liszt. New Edition of the Complete Works. Series I. Works for piano solo. Bazylea: Bärenreiter Kassel. X-XII. @: http://imslp.eu/files/imglnks/euimg/8/82/IMSLP176822-PMLPo9968-

Liszt_NLA_Serie_I_Band_o6_oo_Vorwort_scan.pdf

Strawiński, I. 1980. Poetyka muzyczna. Przekł. S. Jarociński. Kraków: Polskie Wydawnictwo Muzyczne.

Szymańska-Stułka, K. 2015. Idea przestrzeni $w$ muzyce. Warszawa: Wydawnictwo Uniwersytetu Muzycznego Fryderka Chopina.

Tarasti, E. 2008. Los signos en la historia de la música, historia de la semiótica musical. Tópicos del seminario, 19. 15-71. @: http://www.scielo.org.mx/pdf/tods/n19/n19a2.pdf

Tarasti, E. (red.) 2009. Space in Musical Semiosis. An Abductive Theory of the Musical Composition Process. Helsinki: Hakapaino. @: https://helda.helsinki.fi/bitstream/handle/10138/19374/spaceinm.pdf?seque nce $=2$ 
Katarzyna Płaczek: Między dźwiękiem, stowem i obrazem: o przestrzenności $w$ muzyce

Tagg, P. 2013. Music's Meanings. Nowy Jork: The Mass Media Music Scholar's Press. @: http://tagg.org/bookxtrax/NonMuso/NonMusoAll.pdf

Yourcenar, M. 1998. Aleksis, czyli traktat o daremnych zmaganiach. Przekł. K. Dolatowska. Warszawa: Sic!

Wasilewska-Chmura, M. 2011. Przestrzeń intermedialna literatury i muzyki: muzyka jako model $i$ tworzywo $w$ szwedzkiej poezji późnego modernizmu i awangardy. Kraków: Wydawnictwo Uniwersytetu Jagiellońskiego.

Wójcik, D. 1999. ABC form muzycznych. Kraków: Musica Iagellonica. 